\title{
Diphenyl diselenide and diphenyl ditelluride increase the latency for 4-aminopyridine-induced chemical seizure and prevent death in mice
}

\author{
Verônica B. Brito ${ }^{1 \bowtie}$, João Batista T. Rocha ${ }^{1}$, Vanderlei Folmer ${ }^{1,2}$ and Fernando Erthal ${ }^{1}$ \\ ${ }^{1}$ Departamento de Química, Centro de Ciências Naturais e Exatas, Universidade Federal de Santa Maria, Santa \\ Maria, Brasil; ${ }^{2}$ Universidade Federal do Pampa, Uruguaiana, Brasil
}

Received: 26 October, 2008; revised: 09 February, 2009; accepted: 15 February, 2009

available on-line: 21 February, 2009

\begin{abstract}
In this work was investigated the effect of pre-treatment with $(\mathrm{PhSe})_{2}$ and $(\mathrm{PhTe})_{2}$ on chemical seizure and 4-aminopyridine-induced lethality in mice. Additionally, lipid peroxidation levels of whole brain after treatment with 4 -aminopyridine and effect of pre-treatment with $(\mathrm{PhSe})_{2}$ and $(\mathrm{PhTe})_{2}$ on these levels were investigated. Mice were pre-treated with $(\mathrm{PhSe})_{2}$ or $(\mathrm{PhTe})_{2}(50,100$, or $150 \mu \mathrm{mol} / \mathrm{kg}) 30 \mathrm{~min}$ before 4 -aminopyridine $(12 \mathrm{mg} / \mathrm{kg})$ administration. The treatment with 4 aminopyridine caused a significant incidence of seizures (clonic, tonic) and death. Pre-treatment with (PhSe) ${ }_{2}$ and (PhTe) ${ }_{2}$ significantly increased the latency for clonic and tonic seizures, and prevented 4-aminopyridine-induced death. Significantly, the pre-treatment with $(\mathrm{PhSe})_{2}$ or $(\mathrm{PhTe})_{2}$ increased the latency for clonic seizures in a dose-dependent manner. Additionally, a significant increase was observed in the brain lipid peroxidation level after treatment with 4-aminopyridine, which was significantly inhibited by pre-treatment with $150 \mu \mathrm{mol} / \mathrm{kg}(\mathrm{PhSe})_{2}$ or $(\mathrm{PhTe})_{2}$. These results demonstrate that $(\mathrm{PhSe})_{2}$ and $(\mathrm{PhTe})_{2}$ counteract the harmful effects of 4 -aminopyridine. It is possible that this effect results from modulation of the redox state of $N$-methyl-D-aspartate receptors and/or of $\mathrm{Ca}^{2+}$ channel activity with subsequent alteration in neurotransmitter release. Importantly, this study provides evidence for anticonvulsant and antioxidant properties of $(\mathrm{PhSe})_{2}$ and $(\mathrm{PhTe})_{2}$, which indicates a neuroprotective activity of these compounds.
\end{abstract}

Keywords: seizure, 4-aminopyridine, diphenyl diselenide, diphenyl ditelluride, lipid peroxidation, selenium

\section{INTRODUCTION}

Epilepsy is a collection of diverse disorders that together affect approximately $1-2 \%$ of the world population (Hauser \& Hesdorffer, 1990; Mcnamara, 1999). Although epilepsy can manifest itself in a number of different ways, each type shares the common feature of increased neuronal excitability, culminating in seizures (Lothman et al., 1991; Mcnamara, 1994; 1999). Typically, a seizure episode refers to a transient behaviour change due to abnormal, disordered, and at high-frequency firing of neuron populations in the central nervous system (CNS) (Lothman et al., 1991).

It is well established that excitatory and inhibitory neurotransmission in the CNS is mediated mainly by glutamate and GABA, respectively. Any dysfunction of these neurotransmitter systems, through a decrease in GABAergic and/or an increase in glutamatergic neurotransmission, can be involved in seizure development (Bradford, 1995; Meldrum, 1995). In addition, the amplification of neuronal unbalance that leads to the convulsive episodes, as well its subsidence, involves an interaction of GABAergic

$\square$ Corresponding author: Verônica Bidinotto Brito; Departamento de Química, Centro de Ciências Naturais e Exatas, Universidade Federal de Santa Maria, UFSM, CEP 97105-900, Santa Maria, RS, Brasil; phone: 021-55-8132-3621; e-mail: brito. veronica@gmail.com

Abbreviations: 4-AP, 4-aminopyridine; CNS, central nervous system; DMSO, dimethyl sulfoxide; GPx, glutathione peroxidase; i.p., intraperitoneal; MDA, malondialdehyde; NMDA, N-methyl-D-aspartate; (PhSe) ${ }_{2}$, diphenyl diselenide; (PhTe) diphenyl ditelluride; ROS, reactive oxygen species; SDS, sodium dodecyl sulfate; s.c., subcutaneous; TBARS, thiobarbituric acid reactive species. 
inhibitory and glutamatergic excitatory mechanisms (Meldrum, 1995).

Evidence suggests that oxidative stress, due to an increase in reactive oxygen species (ROS) production, is an important factor involved in seizureinduced neuronal damage (Liang et al., 2007; Santos et al., 2008; Xin et al., 2008). This involvement is supported partially by observations that the oxidation of cellular macromolecules is increased by excitotoxins which produce seizures (Liang et al., 2000; Kaneko et al., 2002). Moreover, overactivation of excitatory amino-acid receptors can trigger the ROS formation, resulting in excitotoxic process (Arriba et al., 2006; Mueller-Burke et al., 2008) and in neuronal damage (Montiel et al., 2005). Importantly, it has been demonstrated that the cell death resultant from excitotoxic processes can be prevented by antioxidants (Cho \& Lee, 2004; Liang et al., 2007; Santos et al., 2008). In fact, brain tissue is a vulnerable target of oxidative processes due to its composition and metabolic conditions, such as high oxygen consumption, high blood flow, and high concentration of neurotransmitters and polyunsaturated fatty acids (Clemens \& Penetta, 1995) which can be oxidized.

4-Aminopyridine (4-AP) is a $\mathrm{K}^{+}$channel blocker and $\mathrm{Ca}^{2+}$ channel stimulator, both voltagedependent gated (Thesleff, 1980; Rogawski \& Barker, 1983), which shows convulsant action when administered systemically or intracerebrally to a variety of species (Schafer et al., 1973; Spyker et al., 1980; Fragoso-Veloz et al., 1990; Yamaguchi \& Rogawski, 1992). Furthermore, the convulsant effects of 4-AP are due to the release of excitatory neurotransmitters (Morales-Villagrán et al., 1996; Peña \& Tapia, 1999), where the augmented glutamate release results in overactivation of excitatory amino-acid receptors, mainly the $N$-methyl-D-aspartate (NMDA)-type. Indeed, an enhancement in the glutamatergic neurotransmission has been linked to the 4-AP convulsant action (Tapia et al., 1999), since the administration of NMDA receptor antagonists protected against 4-APinduced seizures (Fragoso-Veloz \& Tapia, 1992; Morales-Villagrán et al., 1996).

In the last decades, a variety of organic forms of selenium and tellurium have been investigated due to their interesting biological properties. Notably, the redox properties of the selenium and tellurium atoms confer considerable antioxidant activity, suitable as a tool in free-radical biology and medicine (Andersson et al., 1993; Commandeur et al., 2001; Nogueira et al., 2004). In fact, these organochalcogens have been pointed out as possible antioxidant agents because they exhibit glutathione peroxidase-like activity and thus can decompose $\mathrm{H}_{2} \mathrm{O}_{2}$ or a variety of lipid hydroperoxides to $\mathrm{H}_{2} \mathrm{O}$ or appropriate alcohols using GSH or synthetic reduced thiols as electron donors
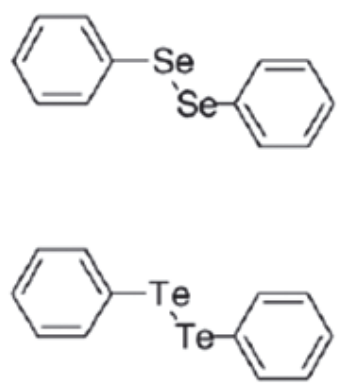

Figure 1. Chemical structure of $(\mathrm{PhSe})_{2}$ and $(\mathrm{PhTe})_{2}$.

(Klotz \& Sies, 2003; Klotz et al., 2003; Nogueira et al., 2004). In addition, the organochalcogens retard the lipid peroxidation induced by a variety of oxidants (Engman et al., 1992; 1995; Rossato et al., 2002a).

In this context, it has been demonstrated that diphenyl diselenide (PhSe) ${ }_{2}$ (Fig. 1) shows an interesting biological activity. It causes minimal toxicity when administrated acutely and in low doses to mice and rats, showing anti-inflammatory, antinociceptive, neuroprotective, chemopreventive, and antioxidant activities (Commandeur et al., 2001; Rossato et al., 2002a; Nogueira et al., 2003b; Posser et al., 2008). Furthermore, (PhSe) ${ }_{2}$ improves the recognition memory of rodents, which may be related to its neuroprotective actions (Rosa et al., 2003). Contrasting with $(\mathrm{PhSe})_{2}$, diphenyl ditelluride $(\mathrm{PhTe})_{2}$ (Fig. 1), its analogous tellurium compound, has demonstrated to be more toxic to rodents than $(\mathrm{PhSe})_{2}$ after acute or prolonged exposure (Nogueira et al., 2001; Widy-Tyszkiewicz et al., 2002; Meotti et al., 2003).

In brief, the purpose of this study was to investigate the effects of pre-treatment with $(\mathrm{PhSe})_{2}$ or $(\mathrm{PhTe})_{2}$ compounds on 4-AP-induced chemical seizure and lethality in mice. Additionally, brain lipid peroxidation levels after treatment with 4-AP, as well as the effect of pre-treatment with $(\mathrm{PhSe})_{2}$ and $(\mathrm{PhTe})_{2}$ on these levels, were investigated. Importantly, this study can be of great value as it suggests novel neuroprotective compounds against convulsant drugs and side effects of clinically used drugs, such as 4-AP.

\section{MATERIALS AND METHODS}

Chemicals. 4-Aminopyridine (4-AP), sodium dodecyl sulfate (SDS), thiobarbituric acid (TBA), and malondialdehyde (MDA) were obtained from Sigma (St. Louis, MO, USA). Tris(hydroxymethyl)aminomethane and sodium chloride were obtained from Merck (Rio de Janeiro, Brazil). All other chemicals were of analytical grade and were obtained from standard commercial suppliers. 
Diphenyl diselenide $(\mathrm{PhSe})_{2}$ and diphenyl ditelluride $(\mathrm{PhTe})_{2}$ were prepared in our laboratory according to literature methods (Paulmier, 1986; Petragnani, 1994). Analysis of ${ }^{1} \mathrm{H}$ NMR and ${ }^{13} \mathrm{C}$ NMR spectra showed that obtained $(\mathrm{PhSe})_{2}$ and $(\mathrm{PhTe})_{2}$ presented analytical and spectroscopic data in full agreement with their assigned structures. The chemical purity of compounds $(99.9 \%)$ was determined by GC/HPLC. These compounds were dissolved in DMSO (dimethyl sulfoxide at concentration of $10 \%$ ).

Animals. Male mice (Mus musculus, about 3 month-old, 30-35 g body mass) from our own breeding colony (Animal House-holding, Federal University of Santa Maria - UFSM, Brazil) were maintained in separate animal's rooms, at $12 \mathrm{~h}$ light/dark cycle (07:00-19:00 $\mathrm{h}$ lights on) and at a room temp. of $22 \pm 2^{\circ} \mathrm{C}$. All animals were fed with a conventional ration $\left(\right.$ Labina $^{\circledR}$, Purina, Canoas, Brazil), and had free access to food and water. The animals were used according to the guidelines of the Committee on Care and Use of Experimental Animal Resources of the Federal University of Santa Maria (Brazil).

\section{In vivo experiments}

4-AP-induced seizures. The animals were pretreated with a single injection of $(\mathrm{PhSe})_{2}$ or $(\mathrm{PhTe})_{2}$ $(50,100$, or $150 \mu \mathrm{mol} / \mathrm{kg}, 2.5 \mathrm{ml}$ per $\mathrm{kg}$ of body mass, subcutaneously (s.c.), dissolved in DMSO) or DMSO alone (vehicle). At $30 \mathrm{~min}$ after administration of organochalcogens, animals were treated with a single injection of 4-AP $(12 \mathrm{mg} / \mathrm{kg}, 2.5 \mathrm{ml}$ per $\mathrm{kg}$ of body mass, intraperitoneally (i.p.), dissolved in water), or water only (vehicle) and were divided as follows:

Group 1 - control [DMSO + water]

Group $2-[\mathrm{DMSO}+4-\mathrm{AP}]$

Group $3-\left[50 \mu \mathrm{mol} / \mathrm{kg}(\mathrm{PhSe})_{2}\right.$ or $(\mathrm{PhTe})_{2}+$ water $]$

Group $4-\left[50 \mu \mathrm{mol} / \mathrm{kg}(\mathrm{PhSe})_{2}\right.$ or $\left.(\mathrm{PhTe})_{2}+4-\mathrm{AP}\right]$

Group $5-\left[100 \mu \mathrm{mol} / \mathrm{kg}(\mathrm{PhSe})_{2}\right.$ or $(\mathrm{PhTe})_{2}+$ water $]$

Group $6-\left[100 \mu \mathrm{mol} / \mathrm{kg}(\mathrm{PhSe})_{2}\right.$ or $\left.(\mathrm{PhTe})_{2}+4-\mathrm{AP}\right]$

Group $7-\left[150 \mu \mathrm{mol} / \mathrm{kg}(\mathrm{PhSe})_{2}\right.$ or $(\mathrm{PhTe})_{2}+$ water $]$

Group $8-\left[150 \mu \mathrm{mol} / \mathrm{kg}(\mathrm{PhSe})_{2}\right.$ or $\left.(\mathrm{PhTe})_{2}+4-\mathrm{AP}\right]$

In short, mice were placed in individual Plex-

iglas chambers $(20 \times 20 \times 19 \mathrm{~cm})$, pre-treated with $(\mathrm{PhSe})_{2}$ or $(\mathrm{PhTe})_{2}$ or vehicle and their behaviour was observed for $30 \mathrm{~min}$ for the appearance of seizures (clonic, tonic) or death. Thereafter the animals were treated with 4-AP and the behaviour was observed for additional $60 \mathrm{~min}$ for the appearance of seizures (clonic, tonic) or death. Appearance of seizures was quantified as previously described by Maggio et al. (1995), as follows, except that recorded seizures lasted at least $5 \mathrm{~s}: 0.5=$ facial myoclonus and forepaw myoclonus; 1 = clonic seizures, lasting at least $15 \mathrm{~s}$ with forelimb clonus, rearing and occasionally falling; 2 explosive clonic seizures with wild running; 3 = tonic forelimb extension; 4 $=$ tonic hindlimb extension. The observed clonic seizures were characterized for the appearance of facial myoclonus, forepaw myoclonus and forelimb clonus lasting at least $5 \mathrm{~s}$. Conversely, tonic seizures were characterized as explosive clonic seizures with wild running and tonic forelimb and hindlimb extension lasting also at least $5 \mathrm{~s}$. Moreover, the latency for the onset of the convulsive episode (clonic or tonic) and the latency for death were recorded as indicators of pro- or anticonvulsive effect of compounds.

The doses of $(\mathrm{PhSe})_{2}$ and $(\mathrm{PhTe})_{2}$ were selected in accordance with previous work which showed typical animal behaviour with the administration of such doses (Meotti et al., 2003; Nogueira et al., 2003a). In addition, the convulsive dose of 4-AP was selected in accordance with Wong et al. (2002).

Ex vivo experiments. At the end of the observation period, animals of groups 1, 7, and 8 were sacrificed under mild ether anesthesia. All animals of group 2 died within $60 \mathrm{~min}$ after administration of 4-AP. Hence, brains of these animals were immediately removed without ether anesthesia and TBARS assay started immediately. Whole brains were quickly removed, placed on ice, and homogenized in ten volumes of cold $50 \mathrm{mM}$ Tris/ $\mathrm{HCl}(\mathrm{pH}$ 7.5). The homogenate was immediately centrifuged at $4000 \times g$ and $4^{\circ} \mathrm{C}$ for $10 \mathrm{~min}$ to yield a low-speed supernatant fraction that was used for Thiobarbituric Acid Reactive Species (TBARS) assay. For the analysis of lipid peroxidation levels only animals pre-treated with $150 \mu \mathrm{mol} / \mathrm{kg}(\mathrm{PhSe})_{2}$ and $(\mathrm{PhTe})_{2}$ were selected, as this dose increased latency for seizures and death more than others.

Lipid peroxidation. TBARS levels were determined according to Ohkawa et al. (1979) with some modifications according to Rossato et al. (2002b). In short, reaction mixture contained $100 \mu \mathrm{L} 8.1 \%$ SDS, $500 \mu \mathrm{L} 1.267 \mathrm{M}$ acetic acid/270 mM HCl (pH 3.5), and $500 \mu \mathrm{L} 0.8 \%$ thiobarbituric acid (TBA). TBARS levels were quantified by addition of $200 \mu \mathrm{L}$ of lowspeed supernatant fraction directly to the above reaction medium. Samples were incubated at $90^{\circ} \mathrm{C}$ for $60 \mathrm{~min}$ and then centrifuged at $1000 \times \mathrm{g}$ for $15 \mathrm{~min}$. The amount of TBARS produced in the supernatant was measured at $532 \mathrm{~nm}$, using MDA for standard curve.

Statistical analysis. Data for latency of onset of the first convulsive episode, clonic or tonic, between groups were analyzed by Kruskal-Wallis analysis of variance followed by the two-tailed MannWhitney U-test. The incidence of seizure and death was analyzed by Fischer's exact test. TBARS values between groups were analyzed by one-way analysis of variance (ANOVA, SPSS for Windows 8.0, SPSS 1998, Chicago, IL, USA) followed by Duncan's Multiple Range Test. Pearson's correlation coefficients 
were determined by linear regression analysis. Results are expressed as means \pm S.E.M., and differences were considered significant when $P<0.05$.

\section{RESULTS}

Table 1 shows that a single administration of 4-AP $(12 \mathrm{mg} / \mathrm{kg})$ caused clonic and tonic seizures in all mice, and all died after administration of this drug. In contrast, pre-treatment of animals with $(\mathrm{PhSe})_{2}$ at doses of 50,100 , or $150 \mu \mathrm{mol} / \mathrm{kg}$ caused a significant latency of clonic seizures and completely prevented the incidence of tonic seizures as well as death. In addition, pre-treatment of mice with (PhSe) ${ }_{2}$ caused an increase in latency for clonic seizures in a dose-dependent manner $(\mathrm{r}$ $=0.880, P<0.001)$. Importantly, when the animals were injected with (PhSe) $)_{2}$ only, in all doses tested, seizures were not observed and the survival was $100 \%$. Also, the pre-treatment with $(\mathrm{PhSe})_{2}$, at all doses tested, reduced the number of animals that presented seizures (clonic and tonic) in relation to animals treated with 4-AP only.

Table 2 shows that pre-treatment with $(\mathrm{PhTe})_{2}$, in all doses tested, significantly increased latency for seizures (clonic and tonic) and completely abolished death. In addition, $150 \mu \mathrm{mol} / \mathrm{kg}$ $(\mathrm{PhTe})_{2}$ completely prevented the appearance of clonic and tonic seizures. As with the $(\mathrm{PhSe})_{2}$, pretreatment of animals with (PhTe $)_{2}$ caused an increase in latency for clonic seizures in a dose-dependent manner $(\mathrm{r}=0.764, P<0.001)$. When animals were injected with $(\mathrm{PhTe})_{2}$ only, in all doses tested, seizures were not observed and survival was $100 \%$. Pre-treatment with $(\mathrm{PhTe})_{2}$, at all doses tested, reduced the number of animals that presented sei-

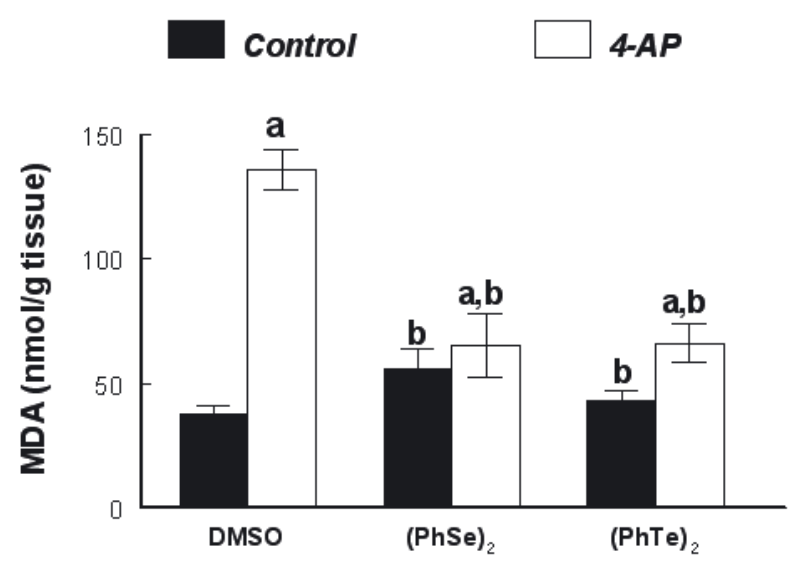

Figure 2. Effects of pre-treatment with $(\mathrm{PhSe})_{2}$ or $(\mathrm{PhTe})_{2}$ and treatment with 4 -AP on TBARS production in mouse brain.

Data are means $\pm S E M ; n=8$. (a) Indicates significant difference from DMSO $(P<0.05)$, and $(b)$ indicates significant difference from DMSO + 4-AP $(P<0.001)$.

zures (clonic and tonic) in relation to animals treated with 4-AP only.

The involvement of oxidative stress in this model of 4-AP-induced seizure was investigated. For this purpose, brain lipid peroxidation levels of groups 1, 2, 7, and 8 were investigated. Figure 2 shows that the administration of 4-AP caused a significant increase, by approx. 4.15 times, in TBARS level in relation to control group (from $37.55 \pm 3.4$ to $135.88 \pm 8.23 \mathrm{nmol} \mathrm{MDA} / \mathrm{g}$ tissue). This effect was significantly inhibited by pre-treatment with 150 $\mu \mathrm{mol} / \mathrm{kg}$ of $(\mathrm{PhSe})_{2}$ or $(\mathrm{PhTe})_{2}$, with a decrease of approx. 2.08 and 2.05 times, respectively, in relation to animals treated with 4-AP only (from $135.88 \pm 8.23$ to $65.25 \pm 12.57 \mathrm{nmol} \mathrm{MDA} / \mathrm{g}$ tissue and to $66.29 \pm 7.99$ nmol MDA/g tissue, respectively).

Table 1. Influence of pre-treatment with $(\mathrm{PhSe})_{2}$ on latency to seizures (clonic and tonic) and death.

\begin{tabular}{|c|c|c|c|c|c|}
\hline Groups* & $\begin{array}{l}\text { Clonic } \\
\text { seizure }\end{array}$ & $\begin{array}{l}\text { Latency for } \\
\text { clonic seizure } \\
\text { (min) }\end{array}$ & $\begin{array}{l}\text { Tonic } \\
\text { seizure }\end{array}$ & $\begin{array}{l}\text { Latency for } \\
\text { tonic seizure } \\
\text { (min) }\end{array}$ & Survival \\
\hline 1 & $0 / 8$ & $60.00 \pm 0.00$ & $0 / 8$ & $60.00 \pm 0.00$ & $8 / 8$ \\
\hline 2 & $8 / 8^{@}$ & $9.13 \pm 1.19^{a}$ & $8 / 8^{@}$ & $18.13 \pm 3.68^{\mathrm{a}}$ & $0 / 8^{\Theta^{* * *}}$ \\
\hline 3 & $0 / 5$ & $60.00 \pm 0.00$ & $0 / 5$ & $60.00 \pm 0.00$ & $5 / 5$ \\
\hline 4 & $6 / 6$ & $20.17 \pm 1.76^{\mathbf{b}}$ & $0 / 6^{\#}$ & $60.00 \pm 0.00^{\mathbf{b}}$ & $6 / 6^{\#}$ \\
\hline 5 & $0 / 5$ & $60.00 \pm 0.00$ & $0 / 5$ & $60.00 \pm 0.00$ & $5 / 5$ \\
\hline 6 & $2 / 7$ & $50.14 \pm 6.36^{\mathbf{b}}$ & $0 / 7^{\#}$ & $60.00 \pm 0.00^{\mathbf{b}}$ & $7 / 7^{\#}$ \\
\hline 7 & $0 / 6$ & $60.00 \pm 0.00$ & $0 / 6$ & $60.00 \pm 0.00$ & $6 / 6$ \\
\hline 8 & $1 / 8$ & $56.38 \pm 3.63^{b}$ & $0 / 8^{\#}$ & $60.00 \pm 0.00^{\mathbf{b}}$ & $8 / 8^{\#}$ \\
\hline
\end{tabular}

After $30 \mathrm{~min}$ of pre-treatment with 50, 100, or $150 \mu \mathrm{mol} / \mathrm{kg}(\mathrm{PhSe})_{2}$ or DMSO, mice were injected with 4-AP (12 mg/kg) or vehicle. After treatment with 4-AP the behaviour was observed for additional $60 \mathrm{~min}$. *Group 1: control [DMSO + water]; Group 2: [DMSO + 4-AP]; Group 3: $\left[50 \mu \mathrm{mol} / \mathrm{kg}(\mathrm{PhSe})_{2}+\right.$ water]; Group 4: $\left[50 \mu \mathrm{mol} / \mathrm{kg}(\mathrm{PhSe})_{2}+4-\mathrm{AP}\right]$; Group 5: $\left[100 \mu \mathrm{mol} / \mathrm{kg}(\mathrm{PhSe})_{2}+\right.$ water $]$; Group 6: [100 $\mu \mathrm{mol} / \mathrm{kg}(\mathrm{PhSe})_{2}+4$-AP]; Group 7: [150 $\mu \mathrm{mol} / \mathrm{kg}(\mathrm{PhSe})_{2}+$ water]; Group 8: [150 $\left.\mu \mathrm{mol} / \mathrm{kg}(\mathrm{PhSe})_{2}+4-\mathrm{AP}\right]$. aSignificantly different from DMSO, $P<0.05$ by Mann-Whitney U-test. bSignificantly different from DMSO + 4-AP, $P<0.05$ by Mann-Whitney U-test. ${ }^{\circledR}$ Significantly different from DMSO, $P<0.05$ by Fisher exact test. "Significantly different from DMSO + 4-AP, $P<0.05$ by Fisher exact test. ${ }^{* *}$ Last animal died at $32.13 \pm 6.42 \mathrm{~min}$. 
Table 2. Influence of pre-treatment with $(\mathrm{PhTe})_{2}$ on latency to seizures (clonic and tonic) and death.

\begin{tabular}{|c|c|c|c|c|c|}
\hline Groups* & $\begin{array}{l}\text { Clonic } \\
\text { seizure }\end{array}$ & $\begin{array}{l}\text { Latency for clonic seizure } \\
\text { (min) }\end{array}$ & $\begin{array}{l}\text { Tonic } \\
\text { seizure }\end{array}$ & $\begin{array}{l}\text { Latency for tonic seizure } \\
\text { (min) }\end{array}$ & Survival \\
\hline 1 & $0 / 8$ & $60.00 \pm 0.00$ & $0 / 8$ & $60.00 \pm 0.00$ & $8 / 8$ \\
\hline 2 & $8 / 8^{@}$ & $9.13 \pm 1.19^{a}$ & $8 / 8^{@}$ & $18.13 \pm 3.68^{\mathrm{a}}$ & $0 / 8^{\Theta^{* * *}}$ \\
\hline 3 & $0 / 5$ & $60.00 \pm 0.00$ & $0 / 5$ & $60.00 \pm 0.00$ & $5 / 5$ \\
\hline 4 & $2 / 6$ & $43.67 \pm 10.45^{b}$ & $1 / 6$ & $51.67 \pm 8.33^{b}$ & $6 / 6^{\#}$ \\
\hline 5 & $0 / 5$ & $60.00 \pm 0.00$ & $0 / 5$ & $60.00 \pm 0.00$ & $5 / 5$ \\
\hline 6 & $2 / 6$ & $46.50 \pm 8.88^{b}$ & $1 / 6$ & $58.33 \pm 1.67^{b}$ & $6 / 6^{\#}$ \\
\hline 7 & $0 / 8$ & $60.00 \pm 0.00$ & $0 / 8$ & $60.00 \pm 0.00$ & $8 / 8$ \\
\hline 8 & $0 / 8^{\#}$ & $60.00 \pm 0.00^{\mathbf{b}}$ & $0 / 8^{\#}$ & $60.00 \pm 0.00^{\mathbf{b}}$ & $8 / 8^{\#}$ \\
\hline
\end{tabular}

After $30 \mathrm{~min}$ of pre-treatment with 50, 100, or $150 \mu \mathrm{mol} / \mathrm{kg}(\mathrm{PhTe})_{2}$ or DMSO, mice were injected with 4-AP (12 mg/kg) or vehicle. After treatment with 4-AP the behaviour was observed for additional $60 \mathrm{~min}$. ${ }^{*}$ Group 1: control [DMSO + water]; Group 2: [DMSO + 4-AP]. Group 3: $\left[50 \mu \mathrm{mol} / \mathrm{kg}(\mathrm{PhTe})_{2}+\right.$ water]; Group 4: [50 $\left.\mu \mathrm{mol} / \mathrm{kg}(\mathrm{PhTe})_{2}+4-\mathrm{AP}\right]$; Group 5: $\left[100 \mu \mathrm{mol} / \mathrm{kg}(\mathrm{PhTe})_{2}+\right.$ water]; Group 6: [100 $\mu \mathrm{mol} / \mathrm{kg}(\mathrm{PhTe})_{2}+4-\mathrm{AP}$; Group 7: [150 $\mu \mathrm{mol} / \mathrm{kg}(\mathrm{PhTe})_{2}+$ water]; Group 8: [150 $\mu \mathrm{mol} / \mathrm{kg}(\mathrm{PhTe})_{2}+4-\mathrm{AP}$. a Significantly different from DMSO, $P<0.05$ by Mann-Whitney U-test. bSignificantly different from DMSO + 4-AP, $P<0.05$ by Mann-Whitney U-test. ${ }^{\circledR}$ Significantly different from DMSO, $P<0.05$ by Fisher exact test. "Significantly different from DMSO +4 -AP, $P<0.05$ by Fisher exact test. ${ }^{* *}$ Last animal died at $32.13 \pm 6.42 \mathrm{~min}$.

\section{DISCUSSION}

Our data demonstrated that administration of $(\mathrm{PhSe})_{2}$ or $(\mathrm{PhTe})_{2}$ previously to the treatment of mice with 4-AP significantly increased the latency for seizures and prevented death. The animals pretreated with $(\mathrm{PhSe})_{2}$ or $(\mathrm{PhTe})_{2}$ showed an increase in the latency for clonic seizures in a dose-dependent manner. In addition, pre-treatment of mice with $150 \mu \mathrm{mol} / \mathrm{kg}(\mathrm{PhSe})_{2}$ or $(\mathrm{PhTe})_{2}$ significantly inhibited the increase in 4-AP-induced TBARS levels. Importantly, this study demonstrated, for the first time, an antioxidant effect of $(\mathrm{PhSe})_{2}$ and $(\mathrm{PhTe})_{2}$ against 4-AP-induced oxidative damage in murine brain, in addition to a marked anticonvulsant effect.

The 4-AP action occurs through a $\mathrm{K}^{+}$-channel blockade at the presynaptic neuron level, mediated by its entry into the channel pore in the open, closed, or intermediate state (Thesleff, 1980; Rogawski \& Barker, 1983). Thereby, efflux of intracellular $\mathrm{K}^{+}$is suppressed and calcium influx is enhanced, leading to an increase in neurotransmitter release and, therefore, to an increase in nervous signal (Molgó et al., 1985). Particularly, this is also the characteristic responsible for the therapeutic properties of 4-AP. In fact, in the last decades, 4-AP has been indicated for the treatment of diverse neuromuscular disorders, including myasthenia gravis, Lambert-Eaton syndrome, and botulism (Lundh et al., 1979; Sellin, 1981; McEvoy et al., 1989). More recently, clinical trials have demonstrated an efficient role of 4-AP in enhancement of the signal conduction after spinal cord trauma (Hayes et al., 1994; Halter et al., 2000; Jensen \& Shi, 2003; McBride et al., 2006), as well as in demyelinizing diseases and multiple sclerosis (Davis et al., 1990). Nevertheless, the clinical use of 4-AP is still limited by its narrow therapeutic range and by the risk of seizures and toxicity to the CNS.

Indeed, 4-AP is used experimentally for induction of seizures in several species (Schafer et al., 1973; Fragoso-Veloz et al., 1990; Spyker et al., 1980; Yamaguchi \& Rogawski, 1992). Our results are in close agreement with literature data showing that all mice developed seizures after systemic administration of $12 \mathrm{mg} / \mathrm{kg} 4-\mathrm{AP}$. When this drug is perfused in the striatum or hippocampus it generates behavioural and electroencephalographic seizures associated with an increase in the extracellular concentration of glutamate (Morales-Villagrán \& Tapia, 1996; Peña \& Tapia 1999). In addition, evidence has shown that an enhancement in glutamatergic neurotransmission is involved in the excitotoxic mechanisms of the seizures (Fragoso-Veloz \& Tapia, 1992; Morales-Villagrán et al., 1996), and seems to be an important factor involved in many neurological disorders (Choi, 1988; Aarts \& Tymianski, 2003; Alexander \& Godwin, 2006). Taking into account these facts and the anticonvulsant action of $(\mathrm{PhSe})_{2}$ and $(\mathrm{PhTe})_{2}$ found in this work, it is possible to presume that through its wide redox activity, these organochalcogens directly interact with glutamatergic receptors, particularly the NMDA receptor, modulating its redox state. Hence, through a decrease in the over-activity of NMDA receptors, these organochalcogens can reduce glutamatergic neurotransmission and incidence of seizures. Moreover, acting as mediators of excitotoxic processes in the CNS, they can reduce the seizure-induced oxidative stress in the brain, manifested by enhanced lipid peroxidation. In this context, recent work has demonstrated that the antinociceptive effect of $(\mathrm{PhSe})_{2}$, in a model of pain, can occur via interaction with redox modulatory sites of glutamatergic receptors, more specifically via 
interaction with the NMDA receptor (Savegnago et al., 2007).

The last decades have witnessed an increasing interest in the biochemical and pharmacological effects of organoselenium and organotellurium compounds due to the finding that a variety of such compounds possess interesting biological activity. Amongst organoselenium compounds, $(\mathrm{PhSe})_{2}$ was emphasized due to its attractive biological properties, such as anti-inflammatory, antinociceptive, neuroprotective, chemopreventive, and antioxidant (Commandeur et al., 2001; Rossato et al., 2002a; Nogueira et al., 2003b; Posser et al., 2008). Many of these activities are related to the biological importance of selenium (Se) as a trace element. In fact, Se has been shown as a nutritionally essential trace element to mammals, including humans (Rayman, 2000). This essentiality is due to selenocystein, a component of selenoproteins like the antioxidant enzyme glutathione peroxidase (GPx), among other selenoproteins that have important enzymatic functions (Behne et al., 1988; Behne \& Kyriakopoulos, 2001; Kyriakopoulos \& Behne, 2002). The fact that brain retains Se even after long-term Se deprivation (Behne et al., 1988) indicates the importance of this trace element to normal brain function. Indeed, several health conditions as immune system deficiency (Spallholz et al., 1990), reproductive problems (Behne et al., 1996), viral infections (Beck et al., 2001), cancer (Ganther, 2001), cardiovascular diseases (Neve, 1996), and seizures (Weber et al., 1991) have been linked to Se deficiency. In this sense, a preclinical study demonstrated the importance of Se deficiency in vivo to substantial increase in susceptibility to kainate-induced seizures in rats (Savaskan et al., 2002). That study showed that Sedeficient rats were more susceptible to kainate-induced excitotoxicity, which resulted in a higher seizure rate when compared with controls on a Seadequate diet. In a model of $\mathrm{Fe}^{2+}$-induced epileptic discharges, application of Se normalized the electroencephalographic pattern and reduced the tissue damage assessed by histological methods (Rubin \& Willmore, 1980; Willmore \& Rubin, 1981). Oztas and coworkers (2001) showed that in pentylentetrazol-induced seizures the breakdown of the bloodbrain barrier is attenuated by dietary Se administration. Additionally, when selenoprotein P (SePP), the major selenoprotein in the plasma, is absent in mice (SePP-knockout mice) reduced growth and development of ataxia are observed (Schomburg et al., 2003).

In 1986, Brown and coworkers suggested a clinical link between seizures and Se deficiency from observations of patients on total parenteral nutrition that were at risk of developing seizures until Se was incorporated into dietary formulation. Later it was shown that intractable epileptic seizures in children with low blood Se concentrations had a substantial improvement in the clinical state and electroencephalography recordings, with reduction of seizures after oral Se supplementation (Ramaekers et al., 1994; Weber et al., 2001). Recent work has demonstrated that patients with intractable epilepsy showed Se depletion compared to healthy children, and suggested that lower serum Se and RBC GPx activity support the concept of a crucial role of Se and GPx activity in the pathogenesis of epilepsy (Ashrafi et al., 2007a; 2007b). These data demonstrate that selenium levels, within the physiological range, attenuate excitatory damage and render it not only a preventive role but also as a putative therapeutic substance in primary neuronal damage. In our study, the administration of $(\mathrm{PhSe})_{2}$ prior to the treatment with 4-AP provided to mice a Se source that was essential for seizure prevention, attenuating the 4-AP-induced excitatory brain damage. Moreover, considering that overactivation of excitatory amino-acid receptors can trigger ROS formation, the inhibition by (PhSe) ${ }_{2}$ of exceeding brain excitatory events can play the central role in the decrease of 4-AP-induced brain lipid peroxidation.

However, the toxicological and pharmacological effects of organochalcogens depend on many factors that include chemical form, quantity of the element consumed, specie and age of animal, physiological state, nutritional and dietary interactions, route and scheme of administration (Maciel et al., 2003; Meotti et al., 2003; Nogueira et al., 2003a; Tingui, 2003). Clarifying this point, it was previously demonstrated that rat pups (12-14 postnatal days) showed seizures after oral administration of 50, 150 or $500 \mathrm{mg} / \mathrm{kg}(\mathrm{PhSe})_{2}(160.3 \mu \mathrm{mol} / \mathrm{kg}, 480.8 \mu \mathrm{mol} / \mathrm{kg}$, or $1602.6 \mu \mathrm{mol} / \mathrm{kg}$, respectively), conversely, rat pups did not present seizures when administered with 5 $\mathrm{mg} / \mathrm{kg}$ (PhSe) ${ }_{2}(16.03 \mu \mathrm{mol} / \mathrm{kg}$ ) (Prigol et al., 2007). In addition, a possible involvement of oxidative stress in (PhSe $)_{2}$-induced seizures in rat pups was suggested. Those results clearly differ from these demonstrated here, however, these discrepancies can be related to differences in experimental model, such as the animal species, route of administration, age of the animals, and doses employed. In our study, adult mice were administered subcutaneously with 50, 100 , or $150 \mu \mathrm{mol} / \mathrm{kg}(\mathrm{PhSe})_{2}(15.6,31.2$, or 46.8 $\mathrm{mg} / \mathrm{kg}$, respectively), doses lower than those used in the cited work. It was previously demonstrated that $(\mathrm{PhSe})_{2}$ administered by the subcutaneous route did not produce seizure or death in male adult mice (Nogueira et al., 2003a). Moreover, the cytochrome P450-dependent metabolism of drugs can vary widely between species and the metabolizing capacity of murine liver is superior to that of the rat, for a variety of drugs. Importantly, the developing brain is 
particularly susceptible to seizures (Stafstrom et al., 2006), which can occur at any age, are far more common in children than adults, predominating in the first year of life and decreasing with age throughout childhood and adolescence (Cowan, 2002).

Similarly to organoselenium, organotellurium compounds can be readily oxidized from the divalent to the tetravalent state. Consequently, this property makes tellurides attractive as scavengers of reactive oxidizing agents (such as hydrogen peroxide, hypochlorite, and peroxyl radicals) and as inhibitors of lipid peroxidation in chemical and biological systems (Andersson et al., 1993; 1994). High antioxidant activity of organotellurium compounds has been described (Engman et al., 1994; 1995). Another point regarding the interesting chemistry of these compounds was reported by Albeck and coworkers in 1998. Those authors showed that organotellurium (IV) compounds can selectively inhibit cysteine proteases in its active-site thiol-nucleophile. Through an interaction of a tellurium atom with the reactive cysteine residues of inflammatory and apoptotic caspases, organotellurium (IV) compounds can lead to caspase inhibition. Indeed, involvement of proinflammatory cytokines in neuronal network excitability was suggested by the evidence that convulsant drugs increase mRNA levels of interleukin IL$1 \beta$, IL-6, and tumor necrosis factor- $\alpha$ (TNF- $\alpha$ ) in rat brain after seizure induction (Minami et al., 1991). Particularly, intracerebral application of IL-1 $\beta$ prolongs the duration of electrographic and behavioral seizures in rodents, and the intracerebral injection of an IL-1 $\beta$ antagonist has a potent anticonvulsant action (Vezzani et al., 1999; 2000). Importantly, caspase- 1 is mainly required for processing pro-IL-1 $\beta$ and pro-IL-18 to their active forms (Fantuzzi et al., 1999), acting as a proconvulsant and its inhibition as an anticonvulsive strategy. The inhibition of caspase1 selectively reduces the brain availability of IL-1 $\beta$ (Ravizza et al., 2006) which can modulate the hyperexcitability process by enhancing glutamatergic neurotransmission (Ye \& Sontheimer, 1996; Kamikawa et al., 1998; Viviani et al., 2003).

In line with this, a recent report described the protective effect of an organotellurium compound - organotelluroxetane RF-07 - against the onset of pilocarpine-induced status epilepticus (Persike et al., 2008). RF-07 is a tellurium (IV) compound that exerts its anticonvulsant effects associated with the inhibition of caspases. In that work the authors demonstrated that caspase- $1,-8$, and 3 are activated in the hippocampus of rats in the acute phase of pilocarpine-induced status epilepticus, and suggest that caspase- 1 activation may exacerbate seizures in the pilocarpine model. Moreover, intraperitoneal injection of RF-07 prior to pilocarpine suppressed seizure occurrence, suggesting a promising therapeutic potential of organotellurium (IV) compounds, through caspase- 1 inhibition, as anticonvulsant and neuroprotective agents (Persike et al., 2008).

Therefore, the findings of the last decades regarding tellurium chemistry corroborate the useful pharmacological effects of organotellurium compounds and their use as promising neuroprotective agents. In this study, as with (PhSe) $)_{2}$, pre-administration of $(\mathrm{PhTe})_{2}$ to animals caused a significant increase in the latency for 4-AP-induced seizures, prevented death, and gave a marked antioxidant effect on 4-AP-induced oxidative brain damage. The inhibition of caspases, specially caspase-1, or modulation of the redox state of excitatory amino-acid receptors are possible mechanisms involved in the anticonvulsant effects of $(\mathrm{PhTe})_{2}$ on 4-AP-induced seizures.

An increase in brain lipid peroxidation levels was observed after treatment with 4-AP, which was significantly inhibited by pre-treatment with $(\mathrm{PhSe})_{2}$ or $(\mathrm{PhTe})_{2}$. Thus, these results confirm the antioxidant property of $(\mathrm{PhSe})_{2}$ and $(\mathrm{PhTe})_{2}$ compounds and show, at first hand, an antioxidant effect of these organochalcogens against 4-AP-induced oxidative damage in murine brain. These effects are in accordance with previous studies of our group, showing that $(\mathrm{PhSe})_{2}$ and $(\mathrm{PhTe})_{2}$ are effective antioxidants against the increase in TBARS production induced by different pro-oxidant agents in vitro and in vivo (Rossato et al., 2002a; Burger et al., 2004; 2006; Meotti et al., 2004). Furthermore, our results point out to an important involvement of brain lipid peroxidation in seizure process, indicating that oxidative stress and the excitotoxic process are important factors involved in seizure-induced neuronal damage (Said et al., 2000; Mueller-Burke et al., 2008; Santos et al., 2008).

Besides the interaction with the redox modulatory sites of glutamatergic NMDA receptors, $(\mathrm{PhSe})_{2}$ and $(\mathrm{PhTe})_{2}$ may interfere with the activity of $\mathrm{Ca}^{2+}$ channels activity in the brain. Thereby, through an inhibition of $\mathrm{Ca}^{2+}$ influx at the presynaptic neuron level, these compounds can modify neurotransmitters' release and conduction of signals. In this way, these organochalcogens may also act as modulators of excitotoxicity in CNS. In fact, a previous study of our group showed that, under depolarizing conditions through 4-AP, organochalcogens inhibited ${ }^{45} \mathrm{Ca}^{2+}$ influx into rat brain synaptosomes (Moretto et al., 2003).

In summary, our results provide evidence for anticonvulsant and antioxidant properties of $(\mathrm{PhSe})_{2}$ and $(\mathrm{PhTe})_{2}$. These data support neuroprotective characteristics of organoselenium and organotellurium compounds in the model of 4-AP-induced neurotoxicity in mice. However, we cannot extrapolate our findings to human and further studies are nec- 
essary to elucidate the protective mechanism(s) of $(\mathrm{PhSe})_{2}$ and $(\mathrm{PhTe})_{2}$ against 4-AP-iduced neurotoxicity.

\section{Conflict of interest statement}

The authors declare no conflict of interest.

\section{REFERENCES}

Aarts MM, Tymianski M (2003) Novel treatment of excitotoxicity: targeted disruption of intracellular signaling from glutamate receptors. Biochem Pharmacol 66: 877-886.

Albeck A, Weitman H, Sredni B, Albeck M (1998) Tellurium compounds: selective inhibition of cysteine proteases and model reaction with thiols. Inorg Chem 37: 1704-1712.

Alexander GM, Godwin DW (2006) Metabotropic glutamate receptors as a strategic target for the treatment of epilepsy. Epilepsy Res 71: 1-22.

Andersson CM, Brattsand R, Hallberg A, Engman L, Persson J, Moldeus P, Cotgreave I (1994) Diaryl tellurides as inhibitors of lipid peroxidation in biological and chemical systems. Free Radic Res 20: 401-410.

Andersson CM, Hallberg A, Brattsand R, Cotgreave IA, Engman L, Persson J (1993) Glutathione peroxidaselike activity of diaryl tellurides. Bioorg Med Chem Lett 3: 2553-2558.

Arriba SG, Krügel U, Regenthal R, Vissiennon Z, Verdaguer E, Lewerenz A, García-Jordá E, Pallas M, Camins A, Münch G, Nieber K, Allgaier C (2006) Carbonyl stress and NMDA receptor activation contribute to methylglyoxal neurotoxicity. Free Radic Biol Med 40: 779-790.

Ashrafi MR, Shabanian R, Abbaskhanian A, Nasirian A, Ghofrani M, Mohammadi M, Zamani GR, Kayhanidoost Z, Ebrahimi S, Pourpak Z (2007a) Selenium and intractable epilepsy: is there any correlation? Ped Neurol 36: 25-29.

Ashrafi MR, Shams S, Nouri M, Mohseni M, Shabanian R, Yekaninejad MS, Chegini N, Khodadad A, Safaralizadeh R (2007b) A Probable causative factor for an old problem: selenium and glutathione peroxidase appear to play important roles in epilepsy pathogenesis. Epilepsia 48: 1750-1755.

Beck MA, Nelson HK, Shi Q, Dael PV, Schiffrin EJ, Blum S, Barclay D, Levander OA (2001) Selenium deficiency increases the pathology of an influenza virus infection. FASEB J 15: 1481-1483.

Behne D, Hilmert H, Scheid S, Gessner H, Elger W (1988) Evidence for specific selenium target tissues and new biologically important selenoproteins. Biochim Biophys Acta 966: 12-21.

Behne D, Kyriakopoulos A (2001) Mammalian seleniumcontaining proteins. Annu Rev Nutr 21: 453-473.

Behne D, Weiler H, Kyriakopoulos A (1996) Effects of selenium deficiency on testicular morphology and function in rats. J Reprod Fertil 106: 291-297.

Bradford HF (1995) Glutamate, GABA and epilepsy. Prog Neurobiol 47: 477-511.

Brown MR, Cohen HJ, Lyons JM, Curtis TW, Thunberg B, Cochran WJ, Klish WJ (1986) Proximal muscle weakness and selenium deficiency associated with long term parenteral nutrition. Am J Clin Nut 43: 549-554.
Burger M, Fachinetto R, Calegari L, Paixão MW, Braga AL, Rocha JBT (2004) Effects of age on reserpine-induced orofacial dyskinesia and possible protection of diphenyl diselenide. Brain Res Bull 64: 339-345.

Burger M, Fachinetto R, Wagner C, Perottoni J, Pereira RP, Zeni G, Rocha JBT (2006) Effects of diphenyl-diselenide on orofacial dyskinesia model in rats. Brain Res Bull 70: 165-170.

Cho J, Lee H (2004) Wogonin inhibits excitotoxic and oxidative neuronal damage in primary cultured rat cortical cells. Eur J Pharmacol 485: 105-110.

Choi DW (1988) Glutamate neurotoxicity and diseases of the nervous system. Neuron 1: 623-634.

Clemens JA, Penetta JA (1995) Free radicals in central nervous systems diseases. In: Immunopharmacology of free radical species. Blake D, Winyard PG, eds, pp 73-83. Academic Press, San Diego.

Commandeur JN, Rooseboom M, Vermeulen NP (2001) Chemistry and biological activity of novel seleniumcontaining compounds. Adv Exp Med Biol 500: 105-112.

Cowan LD (2002) The epidemiology of the epilepsies in children. Ment Retard Dev Disabil Res Rev 8: 171-181.

Davis FA, Stefoski D, Schauf CL (1990) Orally administered 4-aminopyridine improves clinical signs in multiple sclerosis. Ann Neurol 27: 186-192.

Engman L, Persson J, Vessman K, Ekstrom M, Berglund M, Andersson CM (1995) Organotellurium compounds as efficient retards of lipid peroxidation in methanol. Free Rad Biol Med 19: 441-452.

Engman L, Stern D, Cotgreave IA, Andersson CM (1992) Thiol peroxidase activity of diaryl ditellurides as determined by a HNMR method. I Am Chem Soc 114: 9737-9743.

Engman L, Stern D, Pelcman M, Andersson CM (1994) Thiol peroxidase activity of diorganyl tellurides. $M J$ Org Chem 59: 1973-1979.

Fantuzzi G, Reed DA, Dinarello CA (1999) IL-12-induced IFN-gamma is dependent on caspase-1 processing of the IL-18 precursor. J Clin Invest 104: 761-767.

Fragoso-Veloz J, Massieu L, Alvarado R, Tapia R (1990) Seizures and wet dog shakes induced by 4 -aminopyridine, and their potentiation by nifedipine. Eur J Pharmacol 178: 275-284.

Fragoso-Veloz J, Tapia R (1992) NMDA receptor antagonists protect against seizures and wet-dog shakes induced by 4-aminopyridine. Eur J Pharmacol 221: 275280.

Ganther HE (2001) Selenium metabolism and mechanisms of cancer prevention. Adv Exp Med Biol 492: 119-130.

Halter JA, Blight AR, Donovan WH, Calvillo O (2000) Intrathecal administration of 4-aminopyridine in chronic spinal injured patients. Spinal Cord 38: 728-732.

Hauser WA, Hesdorffer DC (1990) Epilepsy: frequency, causes and consequences, pp 1-51. Demos, New York.

Hayes KC, Potter PJ, Wolfe DL, Hsieh JTC, Delaney GA, Blight AR (1994) 4-Aminopyridine-sensitive neurologic deficits in patients with spinal cord injury. J Neurotrauma 11: 433-446.

Jensen JM, Shi R (2003) Effects of 4-aminopyridine on stretched mammalian spinal cord: the role of potassium channels in axonal conduction. J Neurophysiol 90: 2334-2340.

Kamikawa H, Hori T, Nakane H, Aou S, Tashiro N (1998) IL-1 $\beta$ increases norepinephrine level in rat frontal cortex: involvement of prostanoids, $\mathrm{NO}$, and glutamate. Am J Physiol 275: R803-R810.

Kaneko K, Itoh K, Berliner LJ, Miyasaka K, Fujii DH (2002) Consequences of nitric oxide generation in epileptic- 
seizure rodent models as studied by in vivo EPR. Magn Reson Med 48: 1051-1056.

Klotz L, Sies H (2003) Defenses against peroxynitrite: selenocompounds and flavonoids. Toxicol Lett 140: 125132.

Klotz LO, Kroncke KD, Buchczyk DP, Sies H (2003) Role of copper, zinc, selenium and tellurium in the cellular defense against oxidative and nitrosative stress. J Nutr 1333: 1448S-1451S.

Kyriakopoulos A, Behne D (2002) Selenium-containing proteins in mammals and other forms of life. Rev Physiol Biochem Pharm 145: 1-46.

Liang LP, Beaudoin ME, Fritz MJ, Fulton R, Patel M (2007) Kainate-induced seizures, oxidative stress and neuronal loss in aging rats. Neuroscience 147: 1114-1118.

Liang LP, Ho YS, Patel M (2000) Mitochondrial superoxide production in kainate-induced hippocampal damage. Neuroscience 101: 563-570.

Lothman EW, Bertram EH, Stringer JL (1991) Functional anatomy of hippocampal seizures. Prog Neurobiol 37: $1-82$.

Lundh H, Nilsson O, Rosen I (1979) Effects of 4-aminopyridine in myasthenia gravis. J Neurol Neurosurg Psychiatry 42: 171-175.

Maciel EN, Flores EM, Rocha JBT, Folmer V (2003) Comparative deposition of diphenyl diselenide in liver, kidney, and brain of mice. Bull Environ Contam Toxicol 70: 470-476.

Maggio R, Fumagalli F, Donati E, Barbier P, Racagni G, Corsini GU, Riva M (1995) Inhibition of nitric oxide synthase dramatically potentates seizures induced by kainic acid and pilocarpine in rats. Brain Res 679: 184187.

McBride JM, Smith DT, Byrn SR, Borgens RB, Shi R (2006) Dose responses of three 4-aminopyridine derivatives on axonal conduction in spinal cord trauma. Eur $J$ Pharm Sci 27: 237-242.

McEvoy KM, Windebank AJ, Daube NJR, Low PA (1989) 3,4-Diaminopyridine in the treatment of Lambert-Eaton myasthenic syndrome. $N$ Engl J Med 321: 1567-1571.

Mcnamara JO (1994) Cellular and molecular basis of epilepsy. J Neurosci 6: 3413-3425.

Mcnamara JO (1999) Emerging insights into the genesis of epilepsy. Nature 399: A15-A22.

Meldrum B (1995) Neurotransmission in epilepsy. Epilepsy 36: S30-S35.

Meotti FC, Borges VC, Zeni G, Rocha JBT, Nogueira CW (2003) Potential renal and hepatic toxicity of diphenyl diselenide, diphenyl ditelluride and Ebselen for rats and mice. Toxicol Lett 143: 9-16.

Meotti FC, Stangherlin EC, Zeni G, Nogueira CW, Rocha JBT (2004) Protective role of aryl and alkyl diselenides on lipid peroxidation. Environ Res 94: 276-282.

Minami M, Kuraishi Y, Satoh M (1991) Effects of kainic acid on messenger RNA levels of IL-1 $\beta$, IL-6, TNF $\alpha$, and LIF in the rat brain. Biochem Biophys Res Commun 176: $593-598$.

Molgó J, Lemeignan M, Peradejordi F, Lechat P (1985) Effects presynaptiques des aminopyridines a la juntion neuromusculaire de vertébrés. J Pharmacol 16: 109-144.

Montiel T, Camacho A, Estrada-Sánchez AM, Massieu L (2005) Differential effects of the substrate inhibitor Ltrans-pyrrolidine-2,4-dicarboxylate (PDC) and the nonsubstrate inhibitor DL-threo- $\beta$-benzyloxyaspartate (DLTBOA) of glutamate transporters on neuronal damage and extracellular amino acid levels in rat brain in vivo. Neuroscience 133: 667-678.
Morales-Villagrán A, Tapia R (1996) Preferential stimulation of glutamate release by 4 -aminopyridine in rat striatum in vivo. Neurochem Int 28: 35-40.

Morales-Villagrán A, Ureña-Guerrero M, Tapia R (1996) Protection by NMDA receptor antagonists against seizures induced by intracerebral administration of 4-aminopyridine. Eur J Pharmacol 305: 87-93.

Moretto MB, Rossato JI, Nogueira CW, Zeni G, Rocha JBT (2003) Voltage-dependent Ebselen and diorganochalcogenides inhibition of ${ }^{45} \mathrm{Ca}^{2+}$ influx into brain synaptosomes. J Biochem Mol Tox 17: 154-160.

Mueller-Burke D, Koehler RC, Martin LJ (2008) Rapid NMDA receptor phosphorylation and oxidative stress precede striatal neurodegeneration after hypoxic ischemia in newborn piglets and are attenuated with hypothermia. Int J Dev Neurosci 26: 67-76.

Neve J (1996) Seleniumas a risk factor for cardiovascular diseases. J Cardiovasc Risk 3: 42-47.

Nogueira CW, Meotti FC, Curte E, Pilissão C, Zeni G, Rocha JBT (2003a) Investigations into the potential neurotoxicity induced by diselenides in mice and rats. Toxicology 183: 29-37.

Nogueira CW, Quinhones EB, Jung EAC, Zeni G, Rocha JBT (2003b) Evidence for anti-inflammatory and antinociceptive activity of diphenyl diselenide. Inflamm Res 52: 56-63.

Nogueira CW, Rotta LN, Perry ML, Souza DO, Rocha JBT (2001) Diphenyl diselenide and diphenyl ditelluride affect the rat glutamatergic system in vitro and in vivo. Brain Res 906: 157-163.

Nogueira CW, Zeni G, Rocha JBT (2004) Organoselenium and organotellurium compounds: toxicology and pharmacology. Chem Rev 104: 255-285.

Ohkawa H, Ohishi N, Yagi K (1979) Assay for lipid peroxides in animal tissues by thiobarbituric acid reaction. Anal Biochem 95: 351-358.

Oztas B, Kilic S, Dural E, Ispir T (2001) Influence of antioxidants on the blood-brain barrier permeability during epileptic seizures. J Neurosci Res 66: 674-678.

Paulmier C (1986) Selenoorganic functional groups. Selenium reagents and intermediates in organic synthesis, pp 25-51. Pergamon Press, Oxford.

Peña F, Tapia R (1999) Relationships among seizures, extracellular amino acid changes, and neurodegeneration induced by 4 -aminopyridine in rat hippocampus: a microdialysis and electroencephalographic study. J Neurochem 72: 2006-2014.

Persike DS, Cunha RLOR, Juliano L, Silva IR, Rosim FE, Vignoli T, Dona F, Cavalheiro EA, Fernandes MJS (2008) Protective effect of the organotelluroxetane RF07 in pilocarpine-induced status epilepticus. Neurobiol Dis 31: 120-126.

Petragnani N (1994) Tellurium in Organic Synthesis, pp 9-88. Academic Press, London.

Posser T, Franco JL, Santos DA, Rigon AP, Farina M, Dafré AL, Rocha JBT, Leal RB (2008) Diphenyl diselenide confers neuroprotection against hydrogen peroxide toxicity in hippocampal slices. Brain Res 1199: 138-147.

Prigol M, Wilhelm EA, Schneider CC, Rocha JBT, Nogueira CW, Zeni G (2007) Involvement of oxidative stress in seizures induced by diphenyl diselenide in rat pups. Brain Res 1147: 226-232.

Ramaekers VT, Calomme M, Vanden Berghe D, Makropoulos W (1994) Selenium deficiency triggering intractable seizures. Neuropediatrics 25: 217-223.

Ravizza T, Lucas SM, Balosso S, Bernardino L, Ku G, Noé F, Malva J, Randle JC, Allan S, Vezzani A (2006) Inactivation of caspase-1 in rodent brain: a novel anticonvulsive strategy. Epilepsia 47: 1160-1168. 
Rayman MP (2000) The importance of selenium to human health. Lancet 356: 233-241.

Rogawski MA, Barker JL (1983) Effects of 4-aminopyridine on calcium action potentials and calcium current under voltage clamp in spinal neurons. Brain Res 280: 180-185.

Rosa RM, Flores DG, Appelt HR, Braga AL, Henriques JA, Roesler R (2003) Facilitation of long-term object recognition memory by pre-training administration of diphenyl diselenide in mice. Neurosci Lett 341: 217-220.

Rossato JI, Ketzer LA, Centurião FB, Silva SJN, Lüdtke DS, Zeni G, Braga AL, Rubin MA, Rocha JBT (2002a) Antioxidant properties of new chalcogenides against lipid peroxidation in rat brain. Neurochem Res 3: 297-303.

Rossato JI, Zeni G, Mello CF, Rubin MA, Rocha JBT (2002b) Ebselen blocks the quinolinic acid-induced production of thiobarbituric acid reactive species but does not prevent the behavioural alterations produced by intra-striatal quinolinic acid administration in the rat. Neurosci Lett 318: 137-140.

Rubin JJ, Willmore LJ (1980) Prevention of iron-induced epileptiform discharges in rats by treatment with antiperoxidants. Exper Neurol 67: 472-480.

Said SJ, Pakbaz H, Berisha HI, Raza S (2000) NMDA receptor activation: critical role in oxidant tissue injury. Free Rad Biol Med 28: 1300-1302.

Santos LFL, Freitas RLM, Xavier SML, Saldanha GB, Freitas RM (2008) Neuroprotective actions of vitamin C related to decreased lipid peroxidation and increased catalase activity in adult rats after pilocarpine-induced seizures. Pharmacol Biochem Behav 89: 1-5.

Savaskan NE, Bräuer AU, Kühbacher M, Eyüpoglu IY, Kyriakopoulos A, Ninnemann O, Behne D, Nitsch R (2002) Selenium deficiency increases susceptibility to glutamate-induced excitotoxicity. FASEB J 17: 112-114.

Savegnago L, Pinto LG, Jesse CR, Alves D, Rocha JBT, Nogueira CW, Zeni G (2007) Antinociceptive properties of diphenyl diselenide: Evidences for the mechanism of action. Eur J Pharmacol 555: 129-138.

Schafer EWJ, Brunton RB, Cunningham DJ (1973) A summary of the acute toxicity of 4-aminopyridine to birds and mammals. Toxicol Appl Pharmacol 26: 532-538.

Schomburg L, Schweizer U, Holtmann B, Flohe L, Sendtner M, Kohrle J (2003) Gene disruption discloses role of selenoprotein $\mathrm{P}$ in selenium delivery to target tissues. Biochem J 370: 397-402.

Sellin LC (1981) The action of botulinum toxin at the neuromuscular junction. Med Biol 59: 11-20.

Spallholz JE, Boylan LM, Larsen HS (1990) Advances in understanding selenium's role in the immune system. Ann NY Acad Sci USA 587: 123-139.

Spyker DA, Lynch C, Shabanowitz J, Sinn JA (1980) Poisoning with 4-aminopyridine: report of three cases. Clin Toxicol 16: 487-497.

Stafstrom CE, Moshe SL, Swann JW, Nehlig A, Jacobs MP, Schwartzkroin PA (2006) Models of pediatric epilepsies: strategies and opportunities. Epilepsia 47: 1407-1414.
Tapia R, Medina-Ceja L, Pena F (1999) On the relationship between extracellular glutamate, hyperexcitation and neurodegeneration, in vivo. Neurochem Int 34: 23-31.

Thesleff S (1980) Aminopyridines and synaptic transmission. Neuroscience 5: 1413-1419.

Tinggi U (2003) Essentiality and toxicity of selenium and its status in Australia: a review. Toxicol Lett 137: 103110.

Vezzani A, Conti M, De Luigi A, Ravizza T, Moneta D, Marchesi F, De Simoniet MG (1999) Interleukin-1 $\beta$ immunoreactivity and microglia are enhanced in the rat hippocampus by focal kainate application: functional evidence for enhancement of electrographic seizures. $J$ Neurosci 19: 5054-5065.

Vezzani A, Moneta D, Conti M, Richichi C, Ravizza T, De Luigi A, De Simoni MG, Sperk G, Andell-Jonsson S, Lundkvist J, Iverfeldt K, Bartfaiet T (2000) Powerful anticonvulsant action of IL-1 receptor antagonist on intracerebral injection and astrocytic overexpression in mice. Proc Natl Acad Sci USA 97: 11534-11539.

Viviani B, Bartesaghi S, Gardoni F, Vezzani A, Behrens MM, Bartfai T, Binaglia M, Corsini E, Di Luca M, Galli CL, Marinovich M (2003) Interleukin-1 $\beta$ enhances NMDA receptor-mediated intracellular calcium increase through activation of the Src family of kinases. J Neurosci 23: 8692-8700.

Weber GF, Maertens P, Meng XZ, Pippenger CE (1991) Glutathione peroxidase deficiency and childhood seizures. Lancet 337: 1443-1444.

Widy-Tyszkiewicz E, Piechal A, Gajkowska B, Smialek M (2002) Tellurium-induced cognitive deficits in rats are related to neuropathological changes in the central nervous system. Toxicol Lett 131: 203-214.

Willmore IJ, Rubin JJ (1981) Antiperoxidant pretreatment and iron-induced epileptiform discharges in the rat: EEG and histopathologic studies. Neurology 31: 63-69.

Wong JYF, Ross SA, McColl C, Massalas JS, Powney E, Finkelstein DI, Clark M, Horne MK, Berkovic SF, Drago J (2002) Proconvulsant-induced seizures in $\alpha 4$ nicotinic acetylcholine receptor subunit knockout mice. Neuropharmacology 43: 55-64.

Xin Y, Xiao-Guang S, Hong S, Yong-Nan L, Jun Y, YanChun D, Yuan-Gui H (2008) Activation of cerebral peroxisome proliferator-activated receptors gamma exerts neuroprotection by inhibiting oxidative stress following pilocarpine-induced status epilepticus. Brain Res 1200: $146-158$.

Yamaguchi S, Rogawski MA (1992) Effects of anticonvulsant drugs on 4-aminopyridine-induced seizures in mice. Epilepsy Res 11: 9-16.

Ye ZC, Sontheimer H (1996) Cytokine modulation of glial glutamate-uptake: a possible involvement of nitric oxide. Neuroreport 7: 2181-2185. 